\title{
Positive associations between macroalgal species in a rocky intertidal zone and their effects on the physiological performance of Ulva lactuca
}

\author{
Marco A. Molina-Montenegro ${ }^{1, *}$, Alejandro A. Muñoz ${ }^{1}$, Ernesto I. Badano ${ }^{1}$, \\ Billy W. Morales ${ }^{2}$, Katia M. Fuentes ${ }^{3}$, Lohengrin A. Cavieres ${ }^{1}$ \\ ${ }^{1}$ Grupo de investigación en Ecología, Biogeografía y Sistemática (ECOBIOSIS), Departamento de Botánica, \\ ${ }^{2}$ Centro de Investigaciones Oceanográficas del Pacifico Suroriental (COPAS), and \\ ${ }^{3}$ Programa Regional de Oceanografía Física y Clima (PROFC), Universidad de Concepción, Casilla 160-C, Concepción, Chile
}

\begin{abstract}
Positive interactions become more important as physical stress increases. Rocky intertidal habitats display marked desiccation and heat stress gradients, increasing from low- to high-tidal levels. The presence of some macroalgae has been shown to facilitate several intertidal organisms by ameliorating stressful conditions. However, few studies have reported positive interactions among 2 or more macroalgal species, and none has addressed how seaweed canopies could modify the physiological performance of other associated algae along intertidal gradients. Here we report on spatial association patterns of 2 macroalgae (the kelp Macrocystis pyrifera and the green alga Ulva lactuca) occurring along a rocky intertidal vertical gradient in southern Chile. We conducted an evaporative water loss experiment and compared temperature and photosynthetic active radiation beneath the canopy of $M$. pyrifera and on exposed substrates. We compared maximum quantum-yield $\left(F_{\mathrm{v}} / F_{\mathrm{m}}\right.$ ratio $=\left(F_{\mathrm{m}}-F_{0}\right) / F_{\mathrm{m}}$, where $F_{0}$ and $F_{\mathrm{m}}$ are the minimum and maximum chlorophyll fluorescence yields, respectively) and photochemical efficiency in Photosystem II ( $\left.\Phi_{\mathrm{PSII}}\right)$ of $U$. lactuca beneath and away from kelp canopies along the intertidal gradient. Positive association patterns between $M$. pyrifera and U. lactuca were detected at high-tidal areas, while neutral patterns were evident at low-tidal heights. Evaporation, temperature, and PAR were lower beneath kelp canopies. The photosynthetic performance of $U$. lactuca was lower in individuals on exposed substrates compared to those associated with $M$. pyrifera, with this effect being more pronounced in the upper intertidal zone. Our results support the prediction that the importance of positive interactions increases with stress. We suggest that $M$. pyrifera could be acting as a 'nurse species' for $U$. lactuca, possibly extending the vertical distribution of this green alga to high intertidal zones.
\end{abstract}

KEY WORDS: Positive interactions · Facilitation $\cdot$ Physical stress $\cdot$ Desiccation gradient $\cdot$ Macroalgae Photosynthetic performance $\cdot$ Chlorophyll fluorescence $\cdot$ PAR

\section{INTRODUCTION}

Spatial pattern analyses have been widely used to infer on the nature of interactions among organisms, with positive spatial associations having been considered a manifestation of facilitation (Callaway 1995, Hasse 2001, Schenk et al. 2003, Tirado \& Pugnaire 2003). Facilitation has been defined as nontrophic interactions that benefit at least 1 of the participants without negatively affecting the organisms involved (Bertness \& Callaway 1994, Bruno \& Bertness 2000, Bruno et al. 2003). These positive interactions frequently have been reported in stressful habitats, such as deserts (e.g. Franco \& Nobel 1988, Valiente-Banuet et al. 1991, Tirado \& Pugnaire 2003), high-mountain ecosystems (e.g. Callaway et al. 2002, Cavieres et al. 
2002), and salt-marsh environments (e.g. Hacker \& Bertness 1995, Callaway \& Pennings 2000). Bertness \& Callaway (1994) and Brooker \& Callaghan (1998) proposed that both the frequency and the intensity of facilitation increases along environmental stress gradients, with this having been demonstrated in several ecosystems (e.g. Bertness \& Leonard 1997, Bertness et al. 1999, Callaway et al. 2002).

Rocky intertidal zones are stressful habitats due to the high substrate temperatures, strong desiccation, and high levels of solar radiation they experience during periods of low tide (Lively \& Raimondi 1987 , Raffaelli \& Hawkins 1996, Bertness \& Leonard 1997). Therefore, any species able to ameliorate these conditions could be expected to enhance the performance of other species (Bertness et al. 1999). During low-tide periods, some macroalgae have been shown to greatly improve water retention of rocky substrates beneath their canopies (Hay 1981, Bertness \& Grosholz 1985). The presence of these macroalgae facilitates the establishment and survival of several other species such as snails, mussels, crabs, as well as other macroalgae (Brawley \& Johnson 1991, Bertness et al. 1999). However, despite the many reported cases of facilitation in algae, seagrasses, and invertebrates in rocky shores, the large majority of these studies have focused on positive intraspecific grouping effects (e.g. Hay 1981, Holbrook et al. 1991, Bertness \& Leonard 1997). In contrast, few studies have demonstrated facilitative interactions among 2 or more macroalgal species (but see Brawley \& Johnson 1991), and none has indicated how seaweed canopies could modify the physiological performance of other associated algae.

Desiccation due to the exposure to high ambient temperatures during periods of low tide has been shown to result in reduced physiological performance and growth in several macroalgal species (Bewley \& Krochko 1982, Dudgeon et al. 1995, Rico \& Fredriksen 1996). Since high-tidal habitats are exposed to high temperatures and desiccant winds for longer periods than lower tidal levels (Lively \& Raimondi 1987, Bertness \& Leonard 1997), mitigation of desiccation by seaweed canopies would be expected to be more important at the former habitats. Hence, microclimatic improvement by seaweed canopies should produce positive patterns of species associations at high-tidal zones. In contrast, more benign abiotic conditions at low-tidal areas should lead to neutral or negative patterns of species co-occurrence. Further, it could also be suggested that amelioration of stressful abiotic conditions at high-tidal habitats should improve the physiological status of associated macroalgal species.

Here we report on spatial association patterns of 2 macroalgae, the giant kelp Macrocystis pyrifera and the green macroalga Ulva lactuca, occurring along a rocky intertidal vertical gradient in southern Chile. The latter alga is a small thin-fronded foliose species (Hoffmann \& Santelices 1997), and hence can be considered to be highly susceptible to desiccation. Indeed, it usually grows in the lower and midportions of rocky intertidal areas, as well as shallow subtidal habitats along the Chilean coast (Hoffmann \& Santelices 1997). We propose that the presence of M. pyrifera individuals ameliorates physical stress beneath their canopies, resulting in positive spatial associations between this kelp and U. lactuca in the high intertidal zone. We also hypothesize that microclimatic improvement by $M$. pyrifera would result in a greater physiological performance of U. lactuca, expressed as an increase in its photosynthetic efficiency of Photosystem II.

\section{MATERIALS AND METHODS}

Study site and species. We carried out this study in February 2003 at Coliumo Bay $\left(36^{\circ} 35^{\prime} \mathrm{S}, 72^{\circ} 58^{\prime} \mathrm{W}\right)$, $40 \mathrm{~km}$ north of the city of Concepción, southern Chile. This is a wave-protected bay in which the horizontal distance between low and high tide points is typically ca. $25 \mathrm{~m}$. Substrata along the intertidal range consist mostly of rocky platforms and boulders, intermixed with sand (Ruiz \& Giampoli 1981).

The most conspicuous macroalgae occurring in this bay are 2 brown kelp species, Macrocystis pyrifera and Lessonia nigrescens, the green foliose species Ulva lactuca, and the red foliose species Mastocarpus papillatus. Invertebrates such as the bivalve Perumytilus purpuratus, the gastropods Tegula atra and Fissurella spp., and cirripedians Jehlius cirratus are also abundant inhabitants commonly found among these macroalgae (Ruiz \& Giampoli 1981). M. pyrifera forms dense and extensive stands consisting of individuals forming large canopies (>1 m diameter). This species mainly grows on rocky platforms, occasionally occurring on bulky sand. U. lactuca grows to $20-30 \mathrm{~cm}$ in height, growing both beneath the canopy of individuals of $M$. pyrifera as well as on exposed rocky substrates. In Chile, both species are widely distributed from Antofagasta $\left(20^{\circ} 56^{\prime} \mathrm{S}, 67^{\circ} 00^{\prime} \mathrm{W}\right)$ to Tierra del Fuego $\left(53^{\circ} 08^{\prime} \mathrm{S}, 70^{\circ} 55^{\prime} \mathrm{W}\right.$ ) (Hoffmann \& Santelices 1997).

Patterns of association between Macrocystis pyrifera and UIva lactuca. At each of 4 equally distant points along the intertidal gradient $(5,10,15$ and $20 \mathrm{~m}$ away from the low intertidal limit), we randomly selected $10 \mathrm{M}$. pyrifera individuals, having canopies between 40 and $60 \mathrm{~cm}$ in diameter, and registered the occurrence of $U$. lactuca beneath them. For each of 
the studied $M$. pyrifera individuals, we also located a $50 \mathrm{~cm}$ diameter metallic hoop on exposed open substrates ca. 30 to $40 \mathrm{~cm}$ away from the kelp canopy, and registered the occurrence of $U$. lactuca. Thus, occurrence of $U$. lactuca was recorded beneath 10 M. pyrifera canopies and 10 equivalent-sized neighboring exposed substrates. To objectively determine association patterns between the macroalgal species at each point along the gradient, the frequency with which $U$. lactuca was found beneath and away from canopies of $M$. pyrifera was compared with randomization tests (Kikvidze et al. 2001, Badano et al. 2002). Based on the observed number of individuals of $U$. lactuca detected at each point of the intertidal gradient, we randomly generated values of its occurrence beneath and away from the kelp canopy. This procedure was repeated 1000 times, and then we calculated the probability of the observed frequency beneath the kelp (positive association) being generated by chance.

Microclimatic data. To assess microclimatic amelioration by Macrocystis pyrifera, we measured photosynthetic active radiation (PAR, 380 to $710 \mathrm{~nm}$ ) and substrate temperature beneath five 40 to $60 \mathrm{~cm}$ diameter canopies of this macroalga in the high intertidal zone (20 $\mathrm{m}$ away from the low intertidal limit). These measurements were taken at the level of the rocky substrate during a single period of low tide. We also took control measurements of PAR and temperature on neighboring ca. $30 \mathrm{~cm}$ distant exposed open areas. We measured PAR using a quantum sensor (Li-250, LiCor) and temperature with a digital thermometer (871A, Tegam). We assessed the variation of both variables through time by taking measurements beneath the same kelp individuals and open spaces at $1 \mathrm{~h}$ intervals between 08:00 and 14:00 h during that day. Differences in PAR and temperature values between rocky substrates beneath individuals of $M$. pyrifera and exposed open areas, and through time, were assessed with repeated-measures ANOVA (Zar 1999), after testing for normality and homogeneity of variances using the Shapiro-Wilks and Bartlett tests, respectively.

Evaporative water loss experiment. To test whether evaporative water loss is reduced beneath Macrocystis pyrifera canopies during periods of low tide, we placed $10 \times 15 \mathrm{~cm}$ semitransparent white cloth mesh bags filled with vermiculite in the high intertidal zone $(20 \mathrm{~m}$ away from the low intertidal limit). Seven bags were placed beneath 40 to $60 \mathrm{~cm}$ diameter $M$. pyrifera canopies and another 7 bags were placed on exposed open areas ca. $30 \mathrm{~cm}$ away from each replicate kelp individual. Prior to the commencement of the experiment, we submerged all bags in seawater until they reached constant weight. We weighed each bag immediately before placing them on the rocky substrates, and then at 2 and $4 \mathrm{~h}$ after commencing the experiment. Weight differences were used to calculate mean percentage water loss per microsite. Differences in percentage water loss were assessed using 1-way repeatedmeasures ANOVA as described above.

Physiological performance of Ulva lactuca. We selected 4 points along the rocky intertidal gradient (5, 10,15 and $20 \mathrm{~m}$ away from the low intertidal limit) during a morning low-tide period. Five individuals of $U$. lactuca were randomly chosen at each point, each one growing beneath a 40 to $60 \mathrm{~cm}$ diameter Macrocystis pyrifera individual. Additionally, at each point, we also selected another 5 individuals of U. lactuca growing ca. 30 to $50 \mathrm{~cm}$ away from the canopy of each M. pyrifera individual. We measured chlorophyll fluorescence on 1 frond of each $U$. lactuca using a portable pulse-modulated fluorimeter (FMS II, Hansatech) during a sunny day at 09:00, 11:00, and 13:00 h to assess temporal variations in fluorescence during the low-tide period.

To assess the physiological status of Ulva lactuca growing beneath and away from Macrocystis pyrifera canopies, we calculated the maximum quantum yield $\left(F_{\mathrm{v}} / F_{\mathrm{m}}\right.$ ratio) and photochemical efficiency of Photosystem II $\left(\Phi_{\text {PSII }}\right)$. U. lactuca fronds were dark-adapted for 20 min using leafclips. We then applied a weak modulated light pulse $\left(0.4 \mu \mathrm{mol}\right.$ photons $\left.\mathrm{m}^{-2} \mathrm{~s}^{-1}\right)$ to assess the minimum chlorophyll fluorescence yield $\left(F_{0}\right)$, after which we applied a saturating pulse of actinic light (ca. $6000 \mu \mathrm{mol}$ photons $\mathrm{m}^{-2} \mathrm{~s}^{-1}$ ) for $0.7 \mathrm{~s}$ to assess maximum fluorescence yield $\left(F_{\mathrm{m}}\right)$. With these data, we calculated the $F_{\mathrm{v}} / F_{\mathrm{m}}$ ratio as $\left(F_{\mathrm{m}}-F_{0}\right) / F_{\mathrm{m}}$ (Maxwell \& Johnson 2000). Following these measurements, we exposed fronds to full sunlight for $30 \mathrm{~s}$ and measured $\Phi_{\text {PSII }}$ (Maxwell \& Johnson 2000). Both $F_{\mathrm{v}} / F_{\mathrm{m}}$ and $\Phi_{\mathrm{PSII}}$ were automatically determined by the fluorimeter. We assessed differences in both parameters between $U$. lactuca growing beneath and away from the canopies of $M$. pyrifera, along the intertidal gradient, and through time, using 2-way repeated-measures ANOVA.

\section{RESULTS}

\section{Patterns of association between Macrocystis pyrifera and Ulva lactuca}

Positive association patterns between Ulva lactuca and Macrocystis pyrifera were detected at upper intertidal levels (15 and $20 \mathrm{~m}$ away from the low intertidal limit). In contrast, neither positive nor negative associations were found between these macroalgae at points situated at lower tidal levels ( 5 and $10 \mathrm{~m}$ away from the low intertidal limit) (Table 1). 
Table 1. Ulva lactuca. Frequencies of co-occurrence beneath Macrocystis pyrifera canopies and on exposed open areas along the intertidal zone at Coliumo Bay $(5,10,15$ and $20 \mathrm{~m}$ away from the low intertidal limit). Results of randomization analyses for positive associations at each point along the intertidal gradient are shown (critical $\alpha=0.05$ )

\begin{tabular}{|lccc|}
\hline $\begin{array}{l}\text { Distance to the low } \\
\text { intertidal limit }(\mathrm{m})\end{array}$ & $\begin{array}{c}\text { Beneath } \\
\text { M. pyrifera }\end{array}$ & $\begin{array}{c}\text { In open } \\
\text { areas }\end{array}$ & p-value \\
\hline 5 & 4 & 6 & 0.29 \\
10 & 6 & 4 & 0.25 \\
15 & 8 & 2 & 0.03 \\
20 & 9 & 1 & $<0.01$ \\
\hline
\end{tabular}

\section{Effects of Macrocystis pyrifera on microclimate}

Both PAR $\left(F_{1,8}=42160.55, \mathrm{p}<0.01\right)$ and temperature of the rocky substrate $\left(F_{1,8}=5890.34, \mathrm{p}<0.01\right)$ were significantly lower beneath Macrocystis pyrifera canopies than at neighboring exposed open areas. Further, both beneath and away from kelp canopies, PAR $\left(F_{8,64}=1977.15, \mathrm{p}<0.01\right)$ and substrate temperature $\left(F_{8,64}=1671.54, \mathrm{p}<0.01\right)$ increased monotonically
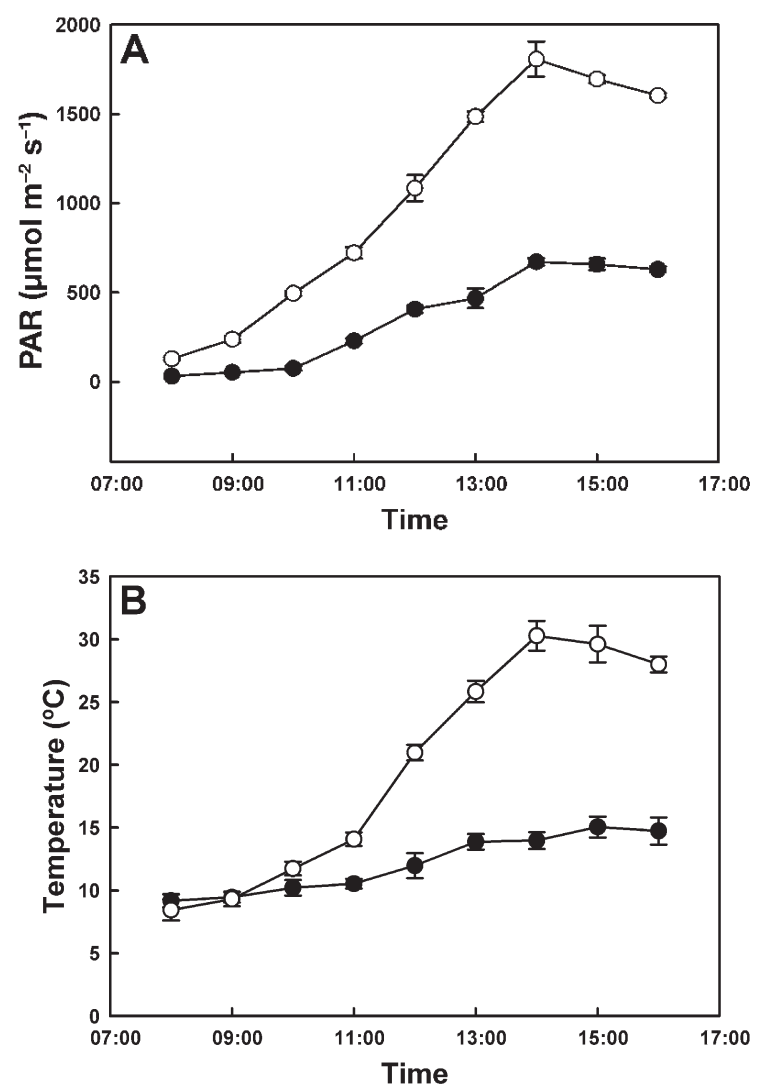

Fig. 1. Daily cycle of (A) photosynthetic active radiation and (B) substrate temperature beneath the canopy of Macrocystis pyrifera individuals $(\bullet)$ and on exposed open areas $(O)$ in a rocky intertidal zone in south-central Chile. Means $\pm 2 \mathrm{SE}$ are shown from the morning towards the afternoon (Fig. 1). However, PAR and substrate temperature remained lower beneath kelp canopies than in neighboring open areas throughout the day (Fig. 1). The largest differences in PAR (Fig. 1A) and temperature (Fig. 1B) between open areas and beneath $M$. pyrifera were registered at 14:00 h, with both microclimatic variables being 4and 3-fold lower below kelp fronds.

\section{Evaporative water loss experiment}

Percentage water loss from experimental bags was significantly lower beneath the canopy of Macrocystis pyrifera than at exposed open areas $\left(F_{3,11}=72.46, \mathrm{p}<\right.$ 0.01; Fig. 2). Further, water loss increased through time, both beneath and away from $M$. pyrifera canopies $\left(F_{3,11}=218.15, \mathrm{p}<0.01\right)$. Experimental bags placed in exposed open areas lost almost twice the amount of water than bags beneath $M$. pyrifera canopies, both at 2 and $4 \mathrm{~h}$ after the commencement of the experiment (Fig. 2).

\section{Physiological performance of UIva lactuca}

Overall, mean values of $F_{\mathrm{v}} / F_{\mathrm{m}}$ from Ulva lactuca individuals associated with Macrocystis pyrifera were higher than from individuals growing in exposed open areas $\left(F_{1,32}=167.53, \mathrm{p}<0.01\right)$. Strong effects of distance to the low-tidal limit $\left(F_{3,32}=70.01, \mathrm{p}<0.01\right.$; Fig. 3A $)$ and time $\left(F_{2,64}=15.22, \mathrm{p}<0.01\right.$; Fig. 3B) were also detected. At the high- and mid-tidal levels, $F_{\mathrm{v}} / F_{\mathrm{m}}$ values of $U$. lactuca associated with $M$. pyrifera were higher than in exposed open areas. In contrast, at the lowest point of the intertidal gradient, no differences in

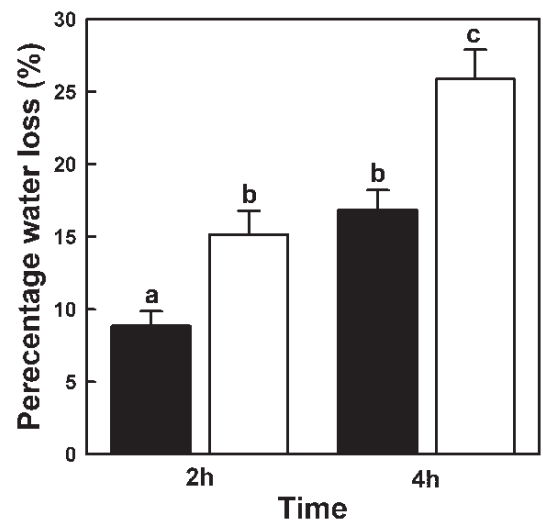

Fig. 2. Percentage water loss (means $\pm 2 \mathrm{SE}$ ) from mesh cloth bags placed beneath the canopy of Macrocystis pyrifera (solid bars) and in exposed open spaces (empty bars) after 2 and $4 \mathrm{~h}$ of exposure in a rocky intertidal zone in south-central Chile. Significant differences between treatment means are denoted with different letters (a posteriori Tukey test $\alpha=0.05$ ) 

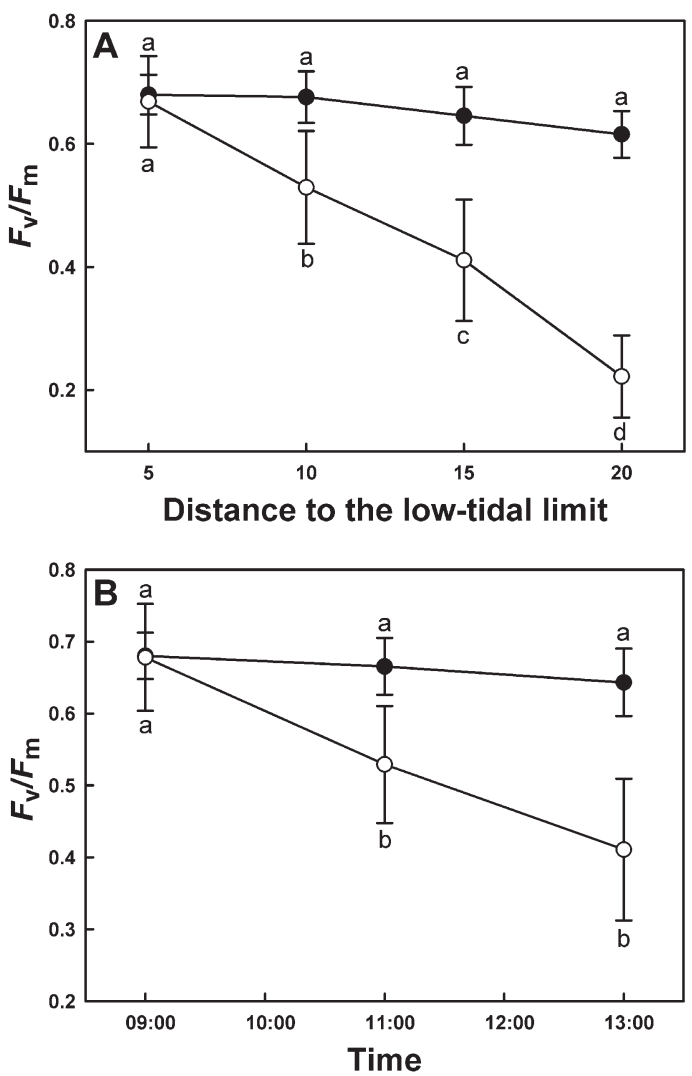

Fig. 3. Ulva lactuca. Maximum quantum yield $\left(F_{\mathrm{v}} / F_{\mathrm{m}}\right.$ ratio $=$ $\left(F_{\mathrm{m}}-F_{0}\right) / F_{\mathrm{m}}$, where $F_{0}$ and $F_{\mathrm{m}}$ are the minimum and maximum chlorophyll fluorescence yields, respectively) of $U$. lactuca beneath the canopy of Macrocystis pyrifera (๑) and on exposed open areas $(0)$ in a rocky intertidal zone in southcentral Chile. Mean values $( \pm 2 \mathrm{SE})$ in $F_{\mathrm{v}} / F_{\mathrm{m}}$ along the intertidal zone (A) and through time (B) are shown. Significant differences between treatments are denoted with different letters (a posteriori Tukey test $\alpha=0.05$ )

$F_{\mathrm{v}} / F_{\mathrm{m}}$ values were detected for $U$. lactuca beneath and away from kelp canopies (Fig. 3A). Although $F_{\mathrm{v}} / F_{\mathrm{m}}$ values for $U$. lactuca beneath and away from $M$. pyrifera did not differ at 09:00 h, they were significantly lower for individuals growing in exposed open areas as time progressed (Fig. 3B).

Likewise, mean $\Phi_{\text {PSII }}$ values for Ulva lactuca in exposed open areas were significantly lower than those of individuals growing beneath the kelp canopy $\left(F_{1,32}=889.47, \mathrm{p}<0.01\right)$. This effect was observed along the entire intertidal gradient $\left(F_{3,32}=279.97, \mathrm{p}<\right.$ $0.01)$, as well as through time $\left(F_{2,64}=64.22, \mathrm{p}<0.01\right)$. Both beneath and away from the canopy of Macrocystis pyrifera, values of $\Phi_{\mathrm{PSII}}$ in $U$. lactuca decreased with increasing distance to the low-tidal limit. In the uppertidal zone, $\Phi_{\text {PSII }}$ beneath kelp canopies was lower than in the other points of the gradient (Fig. 4A). In contrast, $\Phi_{\text {PSII }}$ in exposed open areas showed a consistent decrease along the entire intertidal gradient (Fig. 4A).
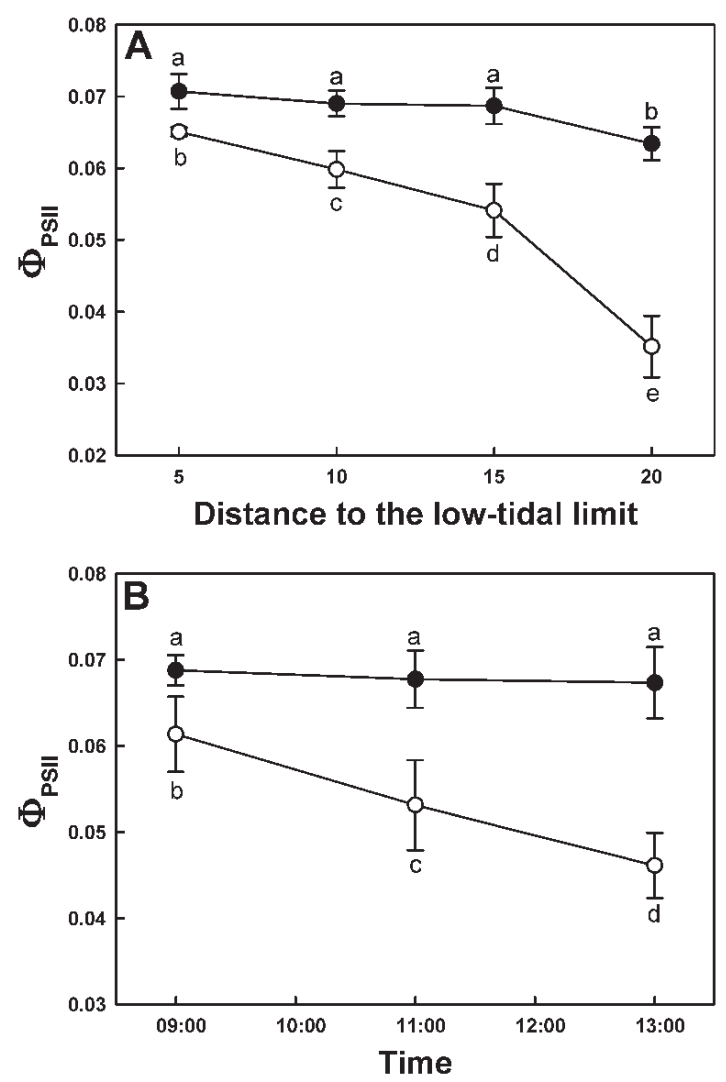

Fig. 4. Ulva lactuca. Chemical efficiency of Photosystem II $\left(\Phi_{\text {PSII }}\right)$ of $U$. lactuca beneath the canopy of Macrocystis pyrifera (๑) and on the open areas (O) in a rocky intertidal zone in south-central Chile. Mean values $( \pm 2 \mathrm{SE})$ of $\Phi_{\text {PSII }}$ along the intertidal zone (A) and through time (B) are shown. Significant differences between treatments are denoted with different letters (a posteriori Tukey test $\alpha=0.05$ )

Values of $\Phi_{\text {PSII }}$ at open areas decreased through time, while those of $U$. lactuca beneath $M$. pyrifera canopies remained constant (Fig. 4B).

\section{DISCUSSION}

Positive association patterns between the macroalgal species Macrocystis pyrifera and Ulva lactuca were detected at the upper levels of the rocky intertidal zone studied, while neither positive nor negative associations were evident at points situated at lowertidal levels. These patterns, coupled with the results of the evaporative water loss experiment, and the lower temperatures and PAR registered beneath kelp canopies in the high intertidal zone, suggest that M. pyrifera may facilitate $U$. lactuca at these more stressful areas of the rocky intertidal zone. Moreover, the greater values of the $F_{\mathrm{v}} / F_{\mathrm{m}}$ ratio and $\Phi_{\mathrm{PSII}}$ in 
$U$. lactuca individuals associated with $M$. pyrifera at the upper-intertidal levels also suggest that this positive association results in an improvement of the physiological performance of $U$. lactuca at these highly desiccant habitats.

The high temperature and levels of desiccation that characterizes intertidal environments generate a very aggressive habitat for living organisms (Raffaelli \& Hawkins 1996, Bertness et al. 1999). Although facilitative interactions have been amply described in stressful marine habitats such as rocky shores and salt marshes (Bruno \& Bertness 2000), most of them are either cases of intraspecific grouping benefits (e.g. Hay 1981, Holbrook et al. 1991, Bertness \& Leonard 1997, Alvarado et al. 2001), or positive effects of algae on recruitment patterns of intertidal inhabitants (Brawley \& Johnson 1991, McCook \& Chapman 1993, Blanchette et al. 1999). Few cases of between-species facilitative interactions at the adult stage have been demonstrated in rocky shores (Turner 1983, Hacker \& Bertness 1995, Bertness et al. 1999). Mechanisms whereby some species produce positive effects on others include amelioration of abiotic stressful conditions, such as a reduction in desiccation, heat stress, and soil salinity (e.g. Bertness \& Hacker 1994, Bertness et al. 1999). In an estuarine rocky intertidal zone in the Gulf of Maine, Bertness et al. (1999) found that the large fucoid macroalga Ascophyllum nodosum reduced evaporative water loss and rock temperatures under their canopies. Here, we found that the positive association patterns between the macroalgal species studied occurred specifically where conditions were more stressful in terms of desiccation (i.e. upper intertidal levels) and where one of the participants, the kelp Macrocystis pyrifera, ameliorates this stress. Studies performed in several stressful habitats have shown that positive spatial associations are strongly correlated with facilitation (Callaway 1995, Hasse 2001, Schenk et al. 2003, Tirado \& Pugnaire 2003). Hence, the significant positive association patterns detected in the high intertidal zone between the macroalgal species studied suggest positive interactions between them. However, removal experiments of kelp canopies are clearly needed to actually demonstrate facilitation of $U$. lactuca by $M$. pyrifera, and to rule out the possibility that both species are converging on favorable microsites for recruitment and/or survival (e.g. Bertness \& Hacker 1994).

On the other hand, although several studies have demonstrated facilitation among intertidal organisms, few of them have concurrently analyzed the consequences of these interactions in terms of the physiological performance of the facilitated species (e.g. Bertness \& Hacker 1994, Hacker \& Bertness 1995). In a New England salt marsh, the removal of Juncus ger- ardi plants at lower marsh levels caused a decrease in soil oxygenation and an increase in soil salinity, resulting in a decrease in photosynthetic rate and biomass of associated Iva frutescens plants compared to those individuals with $J$, gerardi neighbors (Bertness \& Hacker 1994). Our results suggest that canopies of Macrocystis pyrifera ameliorate the stressful desiccation conditions for Ulva lactuca. Indeed, values of $F_{\mathrm{v}} / F_{\mathrm{m}}$ ratios and $\Phi_{\mathrm{PSII}}$ suggest that the photosynthetic performance of $U$. lactuca was improved when associated with $M$. pyrifera. Although the improved physiological status of $U$. lactuca does not necessarily translate into reduced mortality, higher fecundity, or higher recruitment, other authors have shown that decreased photosynthetic performance in macroalgae is related with lower fitness (Littler \& Arnold 1982, Dawes 1998).

Apart from the reduced desiccation, we also found that PAR, another potential physical stress factor in the high-intertidal zone, is reduced beneath the canopies of Macrocystis pyrifera (Fig. 1). Studies conducted in temperate waters off California in shallow subtidal habitats have reported that reduced PAR increased germination and recruitment of kelp (Graham 1996). On the other hand, Irving et al. (2004) recently demonstrated that kelp canopies improve photosynthetic activity of crustose coralline macroalgae by decreasing high levels of PAR in shallow subtidal waters off South Australia. Although, to our knowledge, similar studies have not been conducted in rocky intertidal areas, our results which show an enhanced photosynthetic performance of Ulva lactuca beneath kelp canopies compared to that in exposed open areas may be related not only to a decrease in desiccation stress, but also with amelioration of the stressful high levels of PAR in high-tidal zones.

The presence of Macrocystis pyrifera in highintertidal areas may not only result in a reduction in the levels of PAR, but could also produce a reduction in the impact of other deleterious solar radiation wavelengths, which also increase concomitantly with increasing PAR levels. For example, in intertidal and subtidal macroalgal species it has been shown that an excess of UV-B radiation can produce tissue bleaching, photoinhibition, and damage to proteins, pigments and nucleic acids (Vass 1997, Häder et al. 1998, Bischof et al. 2002). Thus, $M$. pyrifera could also be ameliorating the harmful effects of UV-B radiation on Ulva lactuca, hence resulting in an improvement of its physiological performance, growth and survival.

Positive associations between Ulva lactuca and Macrocystis pyrifera have been previously described by Alveal \& Romo (1977) for several intertidal environments along the southern Chilean coast. These authors defined this algal association as a common phytosociological unit in southern Chile, but they did 
not report vertical changes in the association frequencies between these seaweeds. The spatial patterns detected in this study indicated that positive associations were only evident in the upper tidal zones, suggesting that the occurrence of $U$. lactuca in these sites could depend, at least in part, on the presence of M. pyrifera. Thus, the presence of this kelp species could be extending the realized niche of $U$. lactuca towards the stressful high-intertidal areas (see Bruno et al. 2003).

In this study, both frequencies of association between Macrocystis pyrifera and Ulva lactuca and the physiological performance of the latter increased from low- to high-intertidal levels. These results agree with the models proposed by Bertness \& Callaway (1994) and Brooker \& Callaghan (1998), which predict an increase in the frequency and intensity of positive interactions from low to highly stressful sites. Since upper tidal levels are exposed during longer periods than lower levels, desiccation is expected to be stronger in the former sites (Bertness \& Leonard 1997). In this study, measurements of PAR and temperature were compared between substrates beneath and away from $M$. pyrifera in the high intertidal zone only. However, the fact that we detected a significant enhancement of the physiological performance $\left(F_{\mathrm{v}} / F_{\mathrm{m}}\right.$ and $\left.\Phi_{\text {PSII }}\right)$ of $U$. lactuca at points lower down the intertidal gradient suggests that $M$. pyrifera could also protect $U$. lactuca from desiccation, and high levels of PAR and UV-B, not only in the upper zone of the gradient, but in the lower zone as well. Nevertheless, the random patterns of species association detected in the lowerintertidal areas (Table 1) suggest that abiotic conditions occurring there are more benign than at points higher up, and that the presence of $M$. pyrifera is more important for the persistence of U. lactuca in highintertidal areas.

Physical stress (heat, desiccation and salinity) has been proposed as the main factor structuring shoreline communities (Connell 1972, Raffaelli \& Hawkins 1996). However, recent surveys have emphasized the effects of positive biotic interactions on food-web maintenance and community structure in salt marshes and intertidal zones (Bertness \& Leonard 1997, Hacker \& Gaines 1997, Bruno et al. 2003). Our data support the general idea that the relative importance of facilitation increases toward more stressful habitats along environmental gradients (Bertness \& Callaway 1994, Brooker \& Callaghan 1998), with this being one of the first attempts to include algal associations in this positive interaction framework. However, more research is needed to understand how biotic interactions can influence the performance of algal species in intertidal ecosystems, and how these interactions can affect other organisms.
Acknowledgements. We thank E. Gianoli for helpful suggestions regarding data analysis and K. Alveal for generously providing us with important literature on the intertidal system studied. We thank M. Graham and an anonymous reviewer for helpful suggestions and comments on an earlier version of the manuscript. E.I.B. is currently a doctoral student and A.A.M. a postdoctoral fellow at Universidad de Concepción, Chile, both of whom are supported through MECESUP Grant UCO9906. This paper forms part of the research activities of the Millennium Center for Advanced Studies in Ecology and Research on Biodiversity supported by Grant No. P02-051-F ICM.

\section{LITERATURE CITED}

Alvarado J, Pinto R, Marquet P, Pacheco C, Guiñez R, Castilla JC (2001) Patch recolonization by the tunicate Pyura praeputilialis in the rocky intertidal of the Bay of Antofagasta, Chile: evidence for self-facilitation mechanisms. Mar Ecol Prog Ser 224:93-101

Alveal K, Romo H (1977) Estudios de distribución vertical de la biota costera en el seno de Reloncavi-Chile. Gayana Miscelanea 2:3-28

Badano EI, Molina-Montenegro MA, Quiroz C, Cavieres LA (2002) Efectos de la planta en cojín Oreopolus glacialis (Rubiaceae) sobre la riqueza y diversidad de especies en una comunidad alto-andina de Chile central. Rev Chil Hist Nat 75:757-765

Bertness MD, Callaway RM (1994) Positive interactions in communities. Trends Ecol Evol 9:191-193

Bertness MD, Grosholz T (1985) Population dynamics of the ribbed mussel Geukensia demissa: the costs and benefits of a clumped distribution. Oecologia 67:192-204

Bertness MD, Hacker S (1994) Physical stress and positive associations among marsh plants. Am Nat 144:363-372

Bertness MD, Leonard GH (1997) The role of positive interactions in communities: lessons from intertidal habitats. Ecology 78:1976-1989

Bertness MD, Leonard GH, Levine JM, Schmidt PR, Ingraham AO (1999) Testing the relative contribution of positive and negative interactions in rocky intertidal communities. Ecology 80:2711-2726

Bewley JD, Krochko JE (1982) Desiccation-tolerance. In: Lange OL, Nobel PS, Osmond CB, Ziegler H (eds) Physiological plant ecology. II. Water relations and carbon assimilation. Springer-Verlag, Berlin, p 325-378

Bischof K, Peralta G, Krabs G, van de Poll WH, Perez-Llorens JL, Breeman AM (2002) Effects of solar UV-B radiation on canopy structure of Ulva communities from southern Spain. J Exp Bot 53:2411-2421

Blanchette CA, Worcester SE, Reed D, Holbrook SJ (1999) Algal morphology, flow, and spatially variable recruitment of surfgrass Phyllospadix torreyi. Mar Ecol Prog Ser 184: $119-128$

Brawley SH, Johnson LE (1991) Survival of fucoid embryos in the intertidal zone depends upon developmental stage and microhabitat. J Phycol 27:179-186

Brooker RW, Callaghan TV (1998) The balance between positive and negative plant interactions and its relationships to environmental gradients: a model. Oikos 81:196-207

Bruno JF, Bertness MD (2000) Habitat modification and facilitation in benthic marine communities. In: Bertness MD, Gaines S, Hay M (eds) Marine community ecology. Sinauer, Sunderland, MA, p 201-218

Bruno JF, Stachowicz JJ, Bertness MD (2003) Inclusion of facilitation into ecological theory. Trends Ecol Evol 18: $119-125$ 
Callaway RM (1995) Positive interactions among plants. Bot Rev 61:306-349

Callaway RM, Pennings SC (2000) Facilitation may buffer competitive effects: indirect and diffuse interactions among salt marsh plants. Am Nat 156:416-424

Callaway RM, Brooker R, Choler P, Kikvidze Z and 9 others (2002) Positive interactions among alpine plants increase with stress. Nature 417:844-848

Cavieres LA, Arroyo MTK, Peñaloza A, Molina-Montenegro MA, Torres C (2002) Nurse effect of Bolax gumifera cushion plants in the alpine vegetation of the Chilean Patagonian Andes. J Veg Sci 13:547-554

Connell J (1972) The ecology of rocky shores. Annu Rev Ecol Syst 3:169-192

Dawes CJ (1998) Marine botany. John Wiley \& Sons, New York

Dudgeon SR, Kubler JE, Vadas RL, Vavison IR (1995) Physiological-response to environmental variation in intertidal red algae - does thallus morphology matter? Mar Ecol Prog Ser 117:193-206

Franco AC, Nobel PS (1988) Interaction between seedlings of Agave desertii and the nurse plant Hilaria rigida. Ecology 69:1731-1740

Graham MH (1996) Effect of high irradiance on recruitment of the giant kelp Macrocystis (Phaeophyta) in shallow water. J Phycol 32:903-906

Haase P (2001) Can isotropy vs. anisotropy in the spatial association of plant species reveal physical vs. biotic facilitation. J Veg Sci 12:127-136

Hacker S, Bertness MD (1995) Morphological and physiological consequences of a positive plant interaction. Ecology 76:2165-2175

Hacker SD, Gaines SD (1997) Some implications of direct positive interactions for community species diversity. Ecology 78:1990-2003

Häder DP, Kumar HD, Smith RC, Worrest RC (1998) Effects of aquatic ecosystems. J Photochem Photobiol B 46:53-68

Hay ME (1981) The functional morphological and physiological consequences of a positive plant interaction. Ecology 76:2165-2175

Hoffmann A, Santelices B (1997) Flora marina de Chile central. Ediciones Universidad Católica de Chile, Santiago

Holbrook NM, Denny M, Koehl MAR (1991) Intertidal trees: consequences of aggregation on the mechanical and photosynthetic properties of sea palms. J Exp Mar Biol Ecol 146:39-67

Editorial responsibility: Otto Kinne (Editor-in-Chief), Oldendorf/Luhe, Germany
Irving AD, Connell SD, Elsdon TS (2004) Effects of kelp canopies on bleaching and photosynthetic activity of encrusting coralline algae. J Exp Mar Biol Ecol 310:1-12

Kikvidze Z, Khetsuriani L, Kikodze D, Callaway RM (2001) Facilitation and interference in subalpine meadows of the central Caucasus. J Veg Sci 12:833-838

Littler MM, Arnold KE (1982) Primary productivity of marine macroalgal functional-form groups from southwestern North America. J Phycol 18:307-311

Lively C, Raimondi P (1987) Desiccation, predation, and mussel barnacle interactions in the northern Gulf of California. Oecologia 74:304-309

Maxwell K, Jonson GN (2000) Chlorophyll fluorescence-a practical guide. J Exp Bot 51:659-668

McCook LJ, Chapman ARO (1993) Community succession following massive ice-scour in a rocky intertidal shore: recruitment, competition and predation during early, primary succession. Mar Biol 115:565-575

Raffaelli D, Hawkins S (1996) Intertidal ecology. Chapman \& Hall, London

Rico JM, Fredriksen S (1996) Effects of environmental factors on net photosynthesis and growth of intertidal species of the genus Gelidium (Gelidiaceae, Rhodophyta) in northern Spain. Sci Mar 60:265-273

Ruiz E, Giampoli L (1981) Estudios distribucionales de la flora y fauna costera de Caleta Cocholgue, Bahía de Concepción, Chile. Bol Soc Biol Concepción 52:145-166

Schenk HJ, Holzpfel C, Hamilton JG, Mahall BE (2003) Spatial ecology of a small desert shrub on adjacent geological substrates. J Ecol 91:383-395

Tirado R, Pugnaire PI (2003) Spatial shrub aggregation and consequences for reproductive success. Oecologia 136: 296-301

Turner T (1983) Facilitation as a succecional mechanism in a rocky intertidal community. Am Nat 121:729-738

Valiente-Banuet A, Bolongaro-Crevenna A, Briones O, Ezcurra E, Rosas M, Nuñez H, Barnard G, Vazquez E (1991) Spatial relationships between cacti and nurse shrubs in a semi-arid environment in central Mexico. J Veg Sci 2: $15-20$

Vass I (1997) Adverse effects of UV-B light on the structure and function of the photosynthetic apparatus. In: Pessarakli $\mathrm{M}$ (ed) Handbook of photosynthesis. Marcel Dekker, New York, p 931-949

Zar JH (1999) Biostatistical analysis, 4th edn. Prentice-Hall, Upper Saddle River, NJ

Submitted: May 18, 2004; Accepted: January 13, 2005

Proofs received from author(s): April 12, 2005 